\title{
Use of cimetidine and other peptic ulcer drugs in Denmark 1977-1990 with analysis of the risk of gastric cancer among cimetidine users
}

\author{
H Møller, A Nissen, J Mosbech
}

\begin{abstract}
The prevalence of use of peptic ulcer drugs in the Danish population is described at two points in time using registrations of applications for reimbursement. In 1977-81, the prevalence of use of cimetidine was $0.4 \%$ in men and $0.2 \%$ in women. In $1989-90$, the prevalence of use of peptic ulcer drugs was $1.3 \%$ in men and $1.2 \%$ in women. The increase in prevalence was apparent in all age groups, but most pronounced at relatively old age. The median age of users increased from 55 years in 1977-81 to 63 years in 1989-90. The data indicated that a third of those who used peptic ulcer drugs in 1977-81 also used these drugs in 1989-90, conditional on surviving this period. The probability of becoming a long term user was highest for those who were 50-69 years in 1977-81. The incidence of gastric cancer was investigated in the cohort of persons who used cimetidine in 1977-81. An excess risk of gastric cancer was apparent in the first years after start of cimetidine use. This is thought to reflect a selection bias. Significantly increased incidence was also observed in women seven years or longer after start of cimetidine use ( $R \mathbf{R}=4 \cdot 7 ; 95 \%$ CI: $1 \cdot 7-10 \cdot 3)$. This estimate was, however, based on only six cases, and a similar pattern was not observed in men. (Gut 1992; 33: 1166-1169)
\end{abstract}

Medical treatment of peptic ulcer diseases has gained widespread use since the introduction of $\mathrm{H}_{2}$-receptor blockers in the late 1970 s. Initially, worries were expressed regarding a possible carcinogenic effect of cimetidine, when case reports of gastric carcinoma in cimetidine treated patients appeared. ${ }^{12}$ Epidemiological studies have indeed confirmed an increased occurrence of gastric cancer and other abdominal cancers shortly after start of cimetidine use. The excess risk levels off in the following years and is undoubtedly the result of selection of patients with an unrecognised malignancy at the time of commencement of peptic ulcer treatment..$^{3-6}$ It has been debated whether or not to use medical treatment for ulcer like symptoms, without a full diagnostic procedure being performed. $^{78}$ Finally, the safety of long term maintenance therapy to prevent peptic ulcer recurrence has been discussed but not fully evaluated because barely 15 years have elapsed since their introduction world wide. ${ }^{910}$

A small Danish study showed that in 1984 , maintenance therapy with cimetidine was already common. A third of all prescriptions for cimetidine were given to patients with unproven peptic ulceration, and furthermore, half of these had used the drug for more than five years."

It has been shown that the therapeutic hypochlorhydria which is the primary action of these drugs is associated with increased gastric bacterial growth, reduction of nitrate to nitrite, and increased concentration of carcinogenic $\mathrm{N}$-nitroso compounds in the gastric juice. ${ }^{1213}$ Theoretically, it is possible that long term use of $\mathrm{H}_{2}$ receptor blockers, or the even more potent proton pump inhibitors, could lead to an increased risk of gastric cancer. It is well known that other groups of hypochlorhydric patients - for example, after partial gastrectomy or vagotomy; in chronic atrophic gastritis; in pernicious anaemia - have an increased incidence of gastric cancer. ${ }^{1+17}$ The experience of partial gastrectomy indicates that the time required for de novo growth of gastric carcinoma is about 15 years. ${ }^{14}$ If therapeutic hypochlorhydria is carcinogenic to the stomach, gastric cancer associated with cimetidine use in 1977 should only begin to appear by now.

The present paper describes the prevalence of cimetidine use in the Danish population in the years after its introduction in 1977, and the prevalence of use of peptic ulcer drugs some 10 years later in 1989-90. We attempt to describe also the prevalence of longterm use of peptic ulcer drugs and the epidemiologic risk factors for longterm use in Denmark. A cohort study of gastric cancer incidence among cimetidine users previously published ${ }^{4}$ is extended with additional three years of observation. The maximum duration of follow up of the cohort is now 11 years.

\section{Methods}

\section{CIMETIDINE}

Cimetidine was introduced as a prescription drug in Denmark in 1977 and was accepted for general reimbursement in 1981 . In the period 1977-81, reimbursement of the drug required an individual application from the physician in charge of the patient to the National Board of Health. A registry of these applications for cimetidine use during $1977-81$ is available. The material consisting of 16739 patients who were given the drug for duodenal ulcer, gastric ulcer, gastritis/duodenitis or coexisting duodenal and gastric ulcer, and had neither a history of gastric surgery, nor a history of cancer, has been described previously.

In 1989, it was decided to change peptic ulcer drugs containing cimetidine, ranitidine or sucralfate in general use from prescription drugs 
TABLE I Prevalence of cimetidine use in Denmark 1977-81

\begin{tabular}{|c|c|c|c|c|c|}
\hline $\begin{array}{l}\text { Age group } \\
(y r)\end{array}$ & $\begin{array}{l}\text { Men } \\
(n)\end{array}$ & $\%$ & $\begin{array}{l}\text { Women } \\
(n)\end{array}$ & $\%$ & $\begin{array}{l}\text { Total } \\
(n)\end{array}$ \\
\hline $0-29$ & 662 & 0.06 & 177 & 0.02 & 839 \\
\hline $30-39$ & 1586 & 0.40 & 637 & $0 \cdot 17$ & 2223 \\
\hline $40-49$ & 2076 & 0.73 & 1119 & 0.40 & 3195 \\
\hline $50-59$ & 2630 & 0.95 & 1511 & 0.52 & 4141 \\
\hline $60-69$ & 2232 & 0.94 & 1353 & 0.51 & 3585 \\
\hline $70-79$ & 1192 & 0.82 & 905 & 0.45 & 2097 \\
\hline $80-89$ & 299 & 0.64 & 323 & 0.39 & 622 \\
\hline $90+$ & 17 & $0 \cdot 37$ & 20 & 0.21 & 37 \\
\hline Total & 10694 & 0.42 & 6045 & 0.23 & 16739 \\
\hline
\end{tabular}

TABLE II Prevalence of use of drugs for peptic ulcer in Denmark 1989-90

\begin{tabular}{lclrlr}
\hline $\begin{array}{l}\text { Age group } \\
\text { (yr) }\end{array}$ & $\begin{array}{l}\text { Men } \\
(n)\end{array}$ & $\%$ & $\begin{array}{l}\text { Women } \\
(n)\end{array}$ & \multicolumn{1}{c}{$\%$} & \multicolumn{1}{c}{$\begin{array}{l}\text { Total } \\
(n)\end{array}$} \\
\hline $0-29$ & 1221 & $0 \cdot 12$ & 732 & $0 \cdot 07$ & 1953 \\
$30-39$ & 2559 & 0.68 & 1729 & $0 \cdot 48$ & 4288 \\
$40-49$ & 5192 & 1.33 & 4153 & $1 \cdot 11$ & 9345 \\
$50-59$ & 6308 & $2 \cdot 37$ & 5378 & 1.98 & 11686 \\
$60-69$ & 7532 & $3 \cdot 26$ & 7549 & $2 \cdot 89$ & 15081 \\
$70-79$ & 6551 & $4 \cdot 20$ & 7679 & 3.64 & 14230 \\
$80-89$ & 2462 & $4 \cdot 41$ & 3953 & 3.59 & 6415 \\
$90+$ & 192 & $3 \cdot 18$ & 458 & $2 \cdot 78$ & 650 \\
Total & 32017 & $1 \cdot 27$ & 31631 & $1 \cdot 21$ & 63648 \\
\hline
\end{tabular}

to over the counter distribution. At the same time, the general reimbursement was cancelled for all peptic ulcer drugs. This meant that reimbursement again required an individual application to the National Board of Health. During 1989-90, 63648 users had their applications granted.

The registration of the 1977-81 users consists of the CPR-number (a 10-digit identifier unique to every Danish citizen), date of approval, diagnosis, and method of diagnosis. The registration of the 1989-90 users consists of CPR-number, date of approval, and type of drug.

The 1977-81 material is thought to be essentially complete, except for the exclusion of $12 \%$ who had a previous history of malignancy or had undergone gastric surgery or who were given the drug for another diagnosis than a peptic ulcer related disease. The completeness of the 1989-90 material is more difficult to evaluate because the drugs in this period were available over the counter. The National Board of Health estimates that the use of peptic ulcer drugs without application for partial compensation amounts to some $10 \%$ of the total use. ${ }^{18}$

The prevalence of cimetidine use around 1979 - that is, the proportion of the population using cimetidine anytime in the period 1977-81 - was calculated in 10 year age groups using population data of 1 January 1980, and the prevalence of use of ulcer drugs around 1989 was similarly calcu-

TABLE III Prevalence of use of cimetidine in 1977-81 and use of drugs for peptic ulcer in 1989-90, conditional on survival to 1989

\begin{tabular}{|c|c|c|c|c|c|c|}
\hline \multirow[b]{2}{*}{$\begin{array}{l}\text { Age group } \\
(y r)\end{array}$} & \multirow[b]{2}{*}{$\begin{array}{l}\text { Users } \\
1977-81 \\
n\end{array}$} & \multirow[b]{2}{*}{$\begin{array}{l}\text { Survivors } \\
\text { to } 1989 \\
n(\%)\end{array}$} & \multirow[b]{2}{*}{$\begin{array}{l}\text { Users } \\
1989-90 \\
n(\%)\end{array}$} & \multicolumn{3}{|l|}{ Type of drug } \\
\hline & & & & $\begin{array}{l}\mathrm{H}_{2} \text {-receptor } \\
\text { blockers } \\
n(\%)\end{array}$ & $\begin{array}{l}\text { Omeprazole } \\
n(\%)\end{array}$ & $\begin{array}{l}\text { Other } \\
n(\%)\end{array}$ \\
\hline $\begin{array}{l}0-29 \\
30-39 \\
40-49 \\
50-59 \\
60-69 \\
70-79 \\
80-89 \\
90+ \\
\text { Total }\end{array}$ & $\begin{array}{r}839 \\
2223 \\
3195 \\
4141 \\
3585 \\
2097 \\
622 \\
37 \\
16739\end{array}$ & $\begin{array}{c}823(98) \\
2134(96) \\
2915(91) \\
3443(83) \\
2483(69) \\
989(47) \\
150(24) \\
1(3) \\
12938(77)\end{array}$ & $\begin{array}{c}131(16) \\
544(25) \\
926(32) \\
1273(37) \\
949(38) \\
304(31) \\
41(27) \\
0 \\
4168(32)\end{array}$ & $\begin{array}{r}106(81) \\
444(82) \\
824(89) \\
1125(88) \\
854(90) \\
268(88) \\
37(90) \\
0 \\
3658(88)\end{array}$ & $\begin{array}{c}11(8) \\
56(10) \\
58(6) \\
60(5) \\
40(4) \\
13(4) \\
2(5) \\
0 \\
240(6)\end{array}$ & $\begin{array}{c}14(11) \\
44(8) \\
44(5) \\
88(7) \\
55(6) \\
23(8) \\
2(5) \\
0 \\
270(6)\end{array}$ \\
\hline
\end{tabular}

lated using population data of 1 January 1990. It was not attempted to correct the estimated prevalences for the under registration of ulcer drug users by probably $10 \%$.

Long term use of ulcer drugs was described by linking the list of users in 1977-81 who survived 1 January 1989 to the list of users in $1989-90$ by the CPR number. The linked dataset was tabulated by age at application in 1977-81, by sex, diagnosis, and method of diagnosis in order to evaluate potential risk factors for becoming a longterm user, conditional on surviving to 1989. Multivariate analysis was carried out by unconditional logistic regression analysis. ${ }^{19}$

Finally, extended follow up for gastric cancer incidence among the 1977-81 users of cimetidine was undertaken by record linkage with The Danish Registry of Deaths and The Danish Cancer Registry. ${ }^{20}$ The latter is presently complete up to 1987, and the maximum duration of follow-up is now 11 years.

Cancer incidence in the 1977-81 cohort was compared with cancer incidence in the Danish population as a whole by the use of indirect standardisation for age and period. ${ }^{21}$ Ninety five per cent confidence intervals for the relative risk was calculated using exact probabilities. ${ }^{22}$

\section{Results}

In 1977-81, the prevalence of cimetidine use in the Danish population was $0.42 \%$ in men and $0.23 \%$ in women (Table I). The highest prevalence was seen in the 50-69 age group: $0.9 \%$ in men, $0.5 \%$ in women. Ten years later, the use of peptic ulcer drugs was $1 \cdot 27 \%$ and $1 \cdot 21 \%$ in men and women, respectively (Table II). An increase in prevalence of use was seen in all age groups, and the age of users had shifted towards older age. The prevalence of use in 1989-90 was highest in men in their $80 \mathrm{~s}(4.41 \%)$ and in women in their $70 \mathrm{~s}(3 \cdot 64 \%)$.

Of the 16739 users in $1977-81,12938(77 \%)$ survived to 1989 . Of the survivors, $4168(32 \%)$ were again applying for partial reimbursement of

TABLE IV Risk factors for use of drugs for peptic ulcer in 1989-90 among users of cimetidine in 1977-81 who survived to 1989

\begin{tabular}{|c|c|c|c|c|}
\hline $\begin{array}{l}\text { Age group } \\
(y r)\end{array}$ & $n+/ n-$ & $\begin{array}{l}\text { Crude } \\
\text { odds ratio }\end{array}$ & $\begin{array}{l}\text { Adjusted } \\
\text { odds ratio }\end{array}$ & $\begin{array}{l}95 \% \text { Conf } \\
\text { interval }\end{array}$ \\
\hline $\begin{array}{r}0-29 \\
30-39 \\
40-49 \\
50-59 \\
60-69 \\
70-79 \\
80+\end{array}$ & $\begin{array}{c}131 / 692 \\
544 / 1590 \\
926 / 1989 \\
1273 / 2170 \\
949 / 1534 \\
304 / 685 \\
\cdot 41 / 110\end{array}$ & $\begin{array}{l}0.32 \\
0.58 \\
0.79 \\
1.00 \\
1.05 \\
0.76 \\
0.64\end{array}$ & $\begin{array}{l}0.31 \\
0.57 \\
0.78 \\
1.00 \\
1.07 \\
0.78 \\
0.67\end{array}$ & $\begin{array}{l}0.25-0.38 \\
0.50-0.64 \\
0.70-0.87 \\
\\
0.96-1.19 \\
0.67-0.91 \\
0.46-0.97\end{array}$ \\
\hline \multicolumn{5}{|l|}{ Sex: } \\
\hline $\begin{array}{l}\text { Men } \\
\text { Women }\end{array}$ & $\begin{array}{l}2614 / 5623 \\
1554 / 3147\end{array}$ & $\begin{array}{l}1.00 \\
1.06\end{array}$ & $\begin{array}{l}1 \cdot 00 \\
1 \cdot 03\end{array}$ & $0 \cdot 95 / 1 \cdot 11$ \\
\hline \multicolumn{5}{|l|}{ Diagnosis: } \\
\hline $\begin{array}{l}\text { Duodenal ulcer } \\
\text { Gastric ulcer } \\
\text { Other }\end{array}$ & $\begin{array}{c}2662 / 5310 \\
1087 / 2489 \\
419 / 971\end{array}$ & $\begin{array}{l}1.00 \\
0.87 \\
0.86\end{array}$ & $\begin{array}{l}1.00 \\
0 \cdot 83 \\
0 \cdot 89\end{array}$ & $\begin{array}{l}0.75-0.91 \\
0.78 / 1.01\end{array}$ \\
\hline \multicolumn{5}{|c|}{ Method of diagnosis: } \\
\hline $\begin{array}{l}\text { Endoscopy } \\
\text { Radiograph } \\
\text { Not stated }\end{array}$ & $\begin{array}{r}1151 / 2667 \\
2409 / 4830 \\
608 / 1273\end{array}$ & $\begin{array}{l}1 \cdot 00 \\
1 \cdot 16 \\
1 \cdot 11\end{array}$ & $\begin{array}{l}1 \cdot 00 \\
1 \cdot 16 \\
1 \cdot 09\end{array}$ & $\begin{array}{l}1 \cdot 06-1 \cdot 27 \\
0 \cdot 97-1 \cdot 24\end{array}$ \\
\hline
\end{tabular}


TABLE V Occurrence of gastric cancer (1977-87) among 16739 persons who used cimetidine in 1977-81; by time after start of cimetidine use

\begin{tabular}{|c|c|c|c|c|c|c|c|c|c|}
\hline \multirow[b]{2}{*}{$\begin{array}{l}\text { Time after } \\
\text { start (yr) }\end{array}$} & \multicolumn{3}{|c|}{ Men } & \multicolumn{3}{|c|}{ Women } & \multicolumn{3}{|c|}{ Total } \\
\hline & $n$ & $R R$ & $\begin{array}{l}95 \% \text { Conf } \\
\text { interval }\end{array}$ & $n$ & $R R$ & $\begin{array}{l}95 \% \text { Conf } \\
\text { interval }\end{array}$ & $n$ & $R R$ & $\begin{array}{l}95 \% \text { Con } \\
\text { interval }\end{array}$ \\
\hline $\begin{array}{l}0-1 \\
1-4 \\
4-7 \\
7-11\end{array}$ & $\begin{array}{r}37 \\
20 \\
17 \\
5\end{array}$ & $\begin{array}{l}8 \cdot 1 \\
1.5 \\
1.4 \\
1 \cdot 3\end{array}$ & $\begin{array}{l}5 \cdot 7-11 \cdot 2 \\
0 \cdot 9-2 \cdot 3 \\
0 \cdot 8-2 \cdot 3 \\
0 \cdot 4-3 \cdot 1\end{array}$ & $\begin{array}{r}20 \\
21 \\
8 \\
6\end{array}$ & $\begin{array}{r}12.6 \\
4.5 \\
1.9 \\
4.7\end{array}$ & $\begin{array}{l}7 \cdot 7-19 \cdot 4 \\
2 \cdot 8-6 \cdot 9 \\
0 \cdot 8-3 \cdot 7 \\
1 \cdot 7-10 \cdot 3\end{array}$ & $\begin{array}{l}57 \\
41 \\
25 \\
11\end{array}$ & $\begin{array}{l}9 \cdot 3 \\
2 \cdot 3 \\
1 \cdot 5 \\
2 \cdot 2\end{array}$ & $\begin{array}{l}7 \cdot 0-12 \cdot 0 \\
1 \cdot 6-3 \cdot 1 \\
1 \cdot 0-2 \cdot 3 \\
1 \cdot 1-3 \cdot 9\end{array}$ \\
\hline
\end{tabular}

$R R=$ relative risk

the cost of ulcer drugs in 1989-90 (Table III).

Long term use was most frequent among those who were in their 50s and 60s in 1977-81 (37\%). Among the long term users, the majority of the 1989-90 applications were for $\mathrm{H}_{2}$-receptor blockers (88\%). Omeprazole $(6 \%)$ and other drugs (mainly antacids, bismuth subcitrate and sucralfate) $(6 \%)$ were less commonly applied for. The pattern of use of different drugs among all applicants in $1989-90$ were $80 \% \mathrm{H}_{2}$-receptor blockers, $7 \%$ omeprazole and $13 \%$ other drugs.

Analysis of risk factors for longterm use did not reveal any strong determinants other than age (Table IV). The highest risk of becoming a long term user was seen for those aged 50-69 years in 1977-81. No effect was seen for sex. The probability of becoming a long term user was higher for duodenal ulcer patients than for gastric ulcer patients, and higher for those who had the initial diagnoses based on a radiographic examination rather than endoscopy.

The relative risk of gastric cancer in cimetidine users decreased among men from 8.1 in the first year of follow up to a non-significant 1.3 7-11 years after first use of cimetidine (Table V). In women, however, the data suggested an increased risk of gastric cancer after seven years where the relative risk was $4 \cdot 7(1 \cdot 7-10 \cdot 3)$ after an initial decrease from 12.6 in the first year to 1.9 4-7 years after start of cimetidine use.

\section{Discussion}

The increase in prevalence of medical treatment for peptic ulcer diseases is apparent. The prevalence of use increased more than two-fold from around 1979 to around 1989.

Because of the chronic nature of peptic ulcer diseases, it is likely that a person on medical treatment around 1979 and again around 1989 has used ulcer drugs for a large part of the intermediate period. The data thus show that a large proportion (30-40\%) of those who begin this treatment may become long term users. Because of the incompleteness of the material (described above) all quoted prevalences are probably underestimated by around $10 \%$.

The Danish data show that the potent proton pump inhibitor omeprazole is being commonly used (up to $10 \%$ ), especially among the younger long term users.

The shift in age distribution from a median age at 55 years in the 1977-81 users to 63 years in the 1989-90 users is perhaps the most important finding of the present study. Not only does the use of peptic ulcer drugs increase, but the drugs are increasingly being used by the oldest users in the population. A slight shift in the age distribution would be expected because of the increasing prevalence of non-operated peptic ulcer patients in the population. Similarly, the increasing use of non-steroidal anti-inflammatory drugs may have caused an increasing number of peptic ulcer cases in the older age groups. ${ }^{23}$ These effects can hardly explain a shift in median age from 55 years to 63 years in only a decade, however. A smaller part of the total use of peptic ulcer drugs are being prescribed for diseases other than peptic ulcer - for example, oesophagitis and ZollingerEllison syndrome. Compared with peptic ulcer, these diseases are rare and not particularly prevalent among the oldest in the population. The most important change in the pattern of use of peptic ulcer drugs (especially $\mathrm{H}_{2}$-receptor blockers) is probably that the drugs are increasingly being used to treat non-ulcer dyspepsia and other unspecific gastrointestinal discomfort for which $\mathrm{H}_{2}$-receptor blockers are of little value. ${ }^{24}$

An initial diagnosis of duodenal ulcer and the method of diagnosis being a radiographic examination seems to increase the risk of becoming a long term user of ulcer drugs. Taking age into account does not lead to estimates closer to unity, and hence the effects can not be attributed to confounding. It may be that the effect of diagnosis is real and that duodenal ulcer is more persistent than gastric ulcer, or it may be that a higher proportion of gastric ulcer patients have been operated upon in the time between the two periods of registrations of drug use. Regarding the method of diagnosis, it is hard to imagine that the apparent effect is real. It may be that different subgroups of patients with differences in prognosis have been selected into the two diagnostic procedures.

The follow up for morbidity of gastric cancer shows increased risks in the years after starting cimetidine treatment. This phenomenon has been discussed above and is not the result of a carcinogenic effect of cimetidine but undoubtedly reflects that some patients with gastric cancer were thought to have peptic ulcer and therefore treated with cimetidine. If cimetidine (or the hypochlorhydric condition it creates) is in fact carcinogenic to the gastric mucosa, gastric cancer incidence should be expected to increase only after a period of time after initiation of treatment. The pattern seen among women suggests the possibility of such an effect, but the low number of cases occurring seven years after start of cimetidine use or longer (only six) and the absence of any effect in men speak against the interpretation of the association as being casual. Clearly, the situation warrants further follow up for cancer morbidity in this cohort.

1 Taylor RH, Menzies-Gow N, Lovell D, La Brooy S J, Misiewicz JJ. Misleading response of malignant gastric ulcers to cimetidine. Lancet 1978; i: 686-8.

2 Elder JB, Ganguli PC, Gillespie IE. Cimetidine and gastric cancer. Lancet 1979; i: 1005-6.

3 Colin-Jones DG, Langman MJS, Lawson DH, Vessey MP. Cimetidine and gastric cancer: preliminary report from postCimetidine and gastric cancer: preliminary report from
marketing surveillance study. $B M F 1982 ; 285: 1311-3$.

4 Møller H, Lindvig K, Klefter R, Mosbech J, Jensen OM Cancer occurrence in a cohort of patients treated with Cancer occurrence in a cohort of

5 LaVecchia C, Negri E, D'Avanzo B, Franceschi S. Histamine2-receptor antagonists and gastric cancer risk. Lancet 1990 336: 355-7

6 Schumacher MC, Jick SS, Jick H, Feld AD. Cimetidine use and Gastric Cancer. Epidemiology 1990; 1: 251-4.

7 Heatley RV, Rathbone BJ. Dyspepsia: A dilemma for doctors? Lancet 1987; ii: 779-82. 
8 Hallissey MT, Allum WH, Jewkes AJ, Ellis DJ, Fielding JWL. Early detection of gastric cancer. BMF 1990; 301 513-5.

9 Langman MJS. Antisecretory drugs and gastric cancer. $B M \mathcal{F}$ 1985; 290: 1850-2.

10 Wade AG, Drowley-Jones D. Long term management of duodenal ulcer in general practice: How best to use cimetidine? BMF 1988; 296: 971-4.

11 Gormsen M, Jensen SK, Matzen P, Bonnevie O. Grundlaget for anvendelse af ulcusmedicin i alem praksis. Ugeskr Laeger 1988; 150: 2169-71.

12 Stockbrugger RW, Cotton PB, Eugenides N, Bartholomew $\mathrm{BA}$, Hill MJ, Walters CL. Intragastric nitrites, nitrosamides, and bacterial overgrowth during cimetidine treatment. Gut 1982; 23: 1048-54.

13 Sharma BK, Santana IA, Wood EC, Walt RP, Pereira M, Noone $\mathrm{P}$, et al. Intragastric bacterial activity and nitrosation before, during, and after treatment with omeprazole. $B M F$ 1984; 289: 717-9.

14 Møller H, Toftgaard C. Cancer occurrence in a cohort of patients surgically treated for peptic ulcer. Gut 1991; 32: $740-4$.

15 Watt PCH, Patterson CC, Kennedy TL, Late mortality after vagotomy and drainage for duodenal ulcer. $B M F 1984 ; 288$ : 1335-8.

16 Sipponen $\mathrm{P}$, Kekki M, Haapakoski J, Ihamäki T, Siurala $M$ Gastric cancer risk in chronic atrophic gastritis: statistical
calculations of cross-sectional data. Int $\mathcal{F}$ Cancer 1985; 35: calculation
17 Brinton LA, Gridley G, Hrubec Z, Hoover R, Fraumeni Jr JF. Cancer risk following pernicious anaemia. Br $\mathcal{f}$ Cancer 1989 59: $810-3$

18 Nissen A. Mavesårspræparater: Forbrug, priser og tilskud for og efter 27.3.1989. Ugeskr Laeger 1991; 153: 1436-7.

19 Breslow NE, Day NE, eds. Statistical methods in cancer research. Vol 1. The analysis of case-control studies. IARC Scientific Publications no 32. Lyon: International Agency for Research on Cancer, 1980: 192-246.

20 Storm HH, Manders T, Sprøgel P, Bang S, Jensen OM, eds. Cancer incidence in Denmark 1987. Copenhagen: Danish Cancer incidence in Denmark 1987. Copenh

21 Breslow NE, Day NE, eds. Statistical methods in cancer research. Vol II - The design and analysis of cohort studies. IARC Scientific Publications no 82. Lyon: International Agency for Research on Cancer, 1987: 48-76.

22 Rothman KJ, Boice JD Jr, eds. Epidemiologic analysis with a programmable calculator. Boston: Epidemiology Resources, 1982: 30-1.

23 Griffin MR, Piper JM, Daugherty JR, Snowden M, Ray WA Nonsteroidal anti-inflammatory drug use and increased risk for peptic ulcer disease in elderly persons. Ann Intrn Med 1991; 114: 257-63.

24 Nyren O, Adami HO, Bates S, Bergstrom R, Gustavsson S Loof $\mathrm{L}$, et al. Absence of therapeutic benefit from antacids or cimetidine in non-ulcer dyspepsia. N Engl f Med 1986; 314: 339-43. 